\title{
JUDICIAL CONSIDERATIONS IN THE DETERMINATION \\ OF THE "REASONABLE" LEGAL FEE
}

By HuaH G. IsLEx, JR.*

It is obvious that there can be no mathematical formula for the determination of the legal fee. The evaluation of an attorney's services is controlled by no one factor, but involves a multitude of considerations which vary from case to case not only as to the considerations to be weighed, but also as to the relative weight to be given each. The judicial tribunal is, therefore, faced with a difficult problem when it is called upon to pass on the "reasonableness" of the legal fee. It is the purpose of this article to review those considerations which have found judicial acceptance as affecting the value of legal services rendered.

In an effort to aid the legal profession in fixing the professional fee, the American Bar Association incorporated in its Canons of Professional Ethics, Section 12, which provides as follows:

"In determining the amount of the fee, it is proper to consider: (1) the time and labor required, the novelty and difficulty of the questions involved, and the skill requisite properly to conduct the cause; (2) whether the acceptance of employment in the particular case will preclude the lawyer's appearance for others in cases likely to arise out of the transaction, and in which there is a reasonable expectation that otherwise he would be employed, or will involve the loss of employment in the particular case or antagonisms with other clients; (3) the customary charges of the Bar for similar services; (4) the amount involved in the controversy and the benefits resulting to the client from the services; (5) the contingency or the certainty of the compensation; (6) the character of employment, whether casual or for an established. or constant client. No one of these considerations is controlling. They are mere guides in ascertaining the real value of the service."

It is apparent at the outset that this list is by no means exhaustive; but with few exceptions the considerations enumerated are wholeheartedly accepted by the judiciary as being proper, though not the exclusive, considerations in the computation of the reasonable fee.

* 3rd year law student, Duke University; A.B. Duke, 1951. 
While the courts have, as would be expected, placed great emphasis on the correlation between the time spent in the services of the client and the amount of the fee which may be charged therefor, the weight to be given the time element has been held to be a question of fact for the jury. ${ }^{1}$ Furthermore, the time element to be weighed is not the number of years over which the litigation extended, but the length of time actually devoted to the client's cause. ${ }^{2}$ The attorney's services are to be evaluated on the basis of the time reasonably required to do the job as opposed to the actual time consumed, ${ }^{3}$ and the fact that the attorney has covercd the same territory before in other cases is to be taken into consideration. ${ }^{4}$ It has also been held that the number of attorneys employed does not augment the fee to which they are entitled ${ }^{5}$ as there can be no duplication of charges $;^{6}$ but a different rule is applicable, of eourse, where more than one attorney is actually required. ${ }^{7}$

Closely allied to the consideration of time is the difficulty of the questions involved; for with few exceptions the time reasonably required will vary directly with the difficulty and eomplexity of the problem presented. There is authority to the effect, therefore, that the difficulty of the client's cause and not the time required should be the controlling issue on the grounds that an experienced attorney can accomplish in short order the tasks for which a lesser experienced attorney would require a great deal of time. ${ }^{8}$ The fairness of resorting to such a consideration comes into focus sharply in those cases which hold in effect that lawyers' fees should not be charged for tasks which a clerk can perform cheaper-if not better. ${ }^{9}$ It is interesting to note that in gauging the difficulty encountered in the attorney's rendition of services, the courts have considered such factors as the number of witnesses sworn in at the trial, ${ }^{10}$ the procedural lag, and the size of the record. ${ }^{11}$

${ }^{1}$ Beckjord v. Slusher, 22 Cal. App.2d 678, 72 P.2d 563 (1937).

2 Stucky v. Smith, 148 KY. 401 , 146 S.W.1128 (1912).

s Irvin v. Swinney, 45 F.2d 890 (W. D. Mo. 1930).

4 Shepherd v. Inman-Poulson Lumber Co., 86 Ore. 652, 168 Pac. 601 (1917). Accord as to appeals, rehearings, etc., which were mere restatements of original case, he Kellog, 96 App. Div. 608, 88 N.Y.Supp. 1033 (1st Dep't 1904).

-Schulz v. Schula, 128 Wis. 28, 107 N.W. 302 (1906).

- R. H. MeWilliams, Jr., Co. Inc., v. Missouri-Kansas Pipeline Co., 21 Dol. Ch. 308, 190 Atl. 569 (1936).

7 Re Wallace, 14 F.2d 534 (E. D. Okla. 1926).

${ }^{8}$ Kirchoff v. Bernstein, 92 Ore. 378, 181 Pac. 746 (1919).

${ }^{\circ}$ Re Charles Ray Glass, Inc., 47 F.Supp. 428 (S.D. Cal. 1942); Re Scher'g Estate, 147 Misc. 791, 264 N.Y.Supp. 579 (Surr. Ct. 1933).

${ }^{10}$ Warrenburg v. Cline, 108 Colo. 179, 114 P.2d 302 (1941).

${ }^{11}$ Bricheld v. Dipietro, 152 Fla. 429, 12 S.2d 782 (1943). 
The courts seem to be in unanimous agreement that the amount of the fee may vary with the locality in which the service is rendered. Frequent reference to the minimum fee schedule of the Iocal bar association is made; such reference would seem justified on the grounds that the schedule takes into account the living and operating expenses of the locality in question. ${ }^{12}$ While the schedule is not binding on the court, ${ }^{13}$ it does serve to provide an insight into the consensus of opinion of the local legal profession as to what is a reasonable charge for the services under consideration. ${ }^{14}$

While there is a general judicial recognition of the fact that attorneys cannot always expect compensation on a percentage basis, ${ }^{15}$ it is evident that the amount of the fee should bear some relation to the amount of money or property involved in the case for which services are rendered. Whether this consideration is viewed in the light of the "importance of the cause,"16 the "magnitude of the interest," 17 or the "responsibility assumed by the attorney,"18 the premise is the same, i.e., that the legal fee should vary directly with the amount involved. In the early case of Garfield $v$. Kirk ${ }^{19}$ the court outwardly sanctioned this view, stating that while it may require no more labor to draw a pleading in which $\$ 1,000,000$ is involved than one in which $\$ 10$ is at issue, the additional diligence, care, and labor probably expended on the former pleading must be compensated for. Similarly, it is generally held that the amount of the fee may increase with the amount of the recovery; and even though there is frequently slight correlation between the effort expended and the results obtained, the latter is aeknowledged as an important factor in determining the value of the attorney's services. ${ }^{20}$ Accordingly, the court in the case of Re Hoffman"1 stated that, "Professional services, however able or prolonged, which yield no results command no high regard."

12 Follansbee v. Northwestern Mrut. Life Ins. Co., 87 Ml. App. 609 (1899).

${ }^{13}$ Gaither v. Dougherty, 18 Ky. L. 709, 38 S.W. 2 (1896).

14 Dent v. Foy, 214 Ala. 251, 107 So. 218 (1925).

${ }^{15}$ Wasmuth-Endicott Co. จ. Washington Towers, 110 N.J.Eq. 1, 158 Atl.

836 (1932); Patten v. Pepper Hotel, 153 Cal. 460, 96 Pac. 296 (1908).

${ }^{10}$ Palm Springs-LaQuinta Developments Co. v. Kiebesk Corp., 46 Gal. App.2d 234, 115 P.2d 548 (1941).

${ }_{17}$ Heblich v. Slater, 217 Pa. 404, 66 Atl. 655 (1907).

${ }^{18}$ Hertzog v. Spartanburg Bonded Warehouses, Inc., 184 S.C. 378, 192 S.E. 397 (1937).

${ }^{10} 65$ Barb. 464 (N.Y.Sup.Ct. 1873).

${ }^{20}$ Goss v. Moore, 14 App. Div. 353, 43 N.Y.Supp. 945 (1st Dep't 1897).

${ }^{21} 173$ Fed. 234 (E. D. Wis. 1909). 
While the benefits inuring to the client are obviously a consideration of prime importance in the evaluation of legal services, a more difficult problem arises as to the degree to which the attorney is entitled to compensation based on benefits which inure to the client indirectly from the attorney's success in the immediate case.22 This point is well illustrated in the case of Bruce $v$. Dickey, ${ }^{23}$ in which it was held that future benefits derived by client-city when its bond issue was declared invalid was a proper element of consideration in ascertaining the amount to which the attorncy was entitled. Of course, remote and speculative benefits are not proper items for consideration. ${ }^{24}$

The courts have not hestitated to approve the praetice which allows the more prominent attorney to charge a greater fee than the less eminent lawyer. In the early case of Bowling $v$. Scales ${ }^{25}$ the court stated that the "same services rendered by a young lawyer with his license scarcely dry and by a veteran with forty years experience are measured by a different standard and will entitle each to very different compensation." The court in a Wisconsin case expressed an even stronger attitude:

"There seems to be apparent in this case as well as in some others which have come before us, a notion that any young gentleman two or three ycars out of law school has a right to charge at the rate of $\$ 50$ per day for his services because men of age, experience, and established reputation and eapacity to perform much legal work in one day sometimes or ordinarily receive that much. But this is not corrcet." 20

A statement attributed to a former attorney general of the United States well expressed a recognition of this practice: "A lawyer begins his career by giving $\$ 500$ worth of law for $\$ 5$ and ends it by giving $\$ 5$ worth of law for $\$ 500 . "$ It is worthy of note that while the Canon of Ethics, supra, does not provide for this consideration, its formal recognition is virtually as old as the practice of law itself. $^{27}$

${ }^{22}$ American Nat. Ins. Co. v. Jones, 83 S.W.2d 428 (Tex. Civ. App. 1035), in which it was held that future benefits of insurance payments should bo considered; Behr v. Baker, 255 Mich. 607, 238 N.W. 473 (1031).

23116 III. 527, 6 N.E. 435 (1886).

2 Haish v. Payson, 107 Ill. 365 (1883).

${ }^{25} 1$ Tenn. Ch. 618, 621 (1875).

${ }^{20}$ Szymanski v. Szymanski, 151 Wis. 145, 148, 138 N.W. 53, 54 (1012).

${ }^{27}$ The Afirror (Chap. 2, $\$ 5$ ), cited in Frink v. MeComb, 60 Fed. 486, 489 (C.C.Del. 1894): "[F]our things are to be regarded: (1) the greatness of the cause; (2) pains of the sergeant; (3) his worth, as his learning, eloquence, and gift; (4) the usage of the court." 
The introductory statement in Section 12 of the Canons of Ethics well states the general rule regarding the relation between the amount of the fee and the client's ability to pay: "A client's ability to pay cannot justify a charge in excess of the value of the service, though his poverty may require a less charge or even none at all." Thus it is generally held that the wealth of a client in the majority of cases does not enhance the value of the services $;^{28}$ but the wealth of the client may be of great importance when it pertains to the responsibility assumed by the lawyer. ${ }^{29}$ Similarly, in divorce or separation proceedings the wealth of the client or spouse may be material in ascertaining the fee to which the lawyer is entitled. ${ }^{30}$

It is generally held by the courts as indicated by the Canons of Ethics that the contingency of the attorney's right to compensation is a proper consideration in determining the amount of the legal fee. Thus, it has been held by the greater weight of American authority that an attorney may charge a larger fee when his right to it is contingent. $^{31}$ There is, however, a conflict of authority on this point; for a substantial number of cases have held that the value of legal services are not augmented by the degree of contingency of the attorney's right to compensation. ${ }^{32}$

A factor for consideration which seems to have gained increasing favor with the courts during the last few years is the relation of the legal fee to the economic cycle. The courts have been quick to recognize that the legal fee schedule cannot remain static in the face of ever-changing economic conditions. Thus, in determining the reasonableness of the fee, the courts have noted the rise in the cost of living, ${ }^{33}$ the diminished purchasing power of the

${ }^{28}$ Ward v. Kohn, 58 Fed. 462 (8th Cir. 1893); Scales v. Wynne \& Wynne, 242 S.W. 515 (Tex. Civ. App. 1922).

${ }^{20}$ Sehaper v. Sayman, 61 S.W.2d 379 (St. Louis Ct. App. 1933); Clark v. Ellsworth, 104 Iowa 442,73 N.W. 1023 (1898).

${ }^{30}$ Walker v. Hill, 90 Mont. 111, 300 Pac. 260 (1931); Bowen v. Bowen, 124 Pa. Super. 544, 189 Atl. 529 (1937); Easton v. Simpson, 46 N.Y.S.2d 395 (Sup. Ct. 1944). The latter ease held that it was proper for wife's attorney to examine husband with reference to his current income on the grounds that it was a material consideration in the determination of the attorney's fee.

${ }^{31}$ Campbell County v. Howard, 133 Va. 19, 112 S.E. 876 (1922); Halaska v. Cotzhansen, 52 Wis. 624, 9 N.W. 401 (1881).

${ }^{32} \mathrm{O}$ 'Neill v. Crane, 65 App. Div. 358, 72 N.Y.Snpp. 812 (1st Dep't 1901); Cooke v. Gove, 61 Nev. 55, 114 P.2d 87 (1941); Walbridge v. Barrett, 118 Mlich. 433, 76 N.W. 973 (1898).

${ }^{33}$ Platt v. Shields, 96 Vt. 257, 119 Atl. 520 (1923). 
dollar, ${ }^{34}$ the increase in overhead expenses, ${ }^{35}$ and the general economic conditions of the country. ${ }^{36}$

The foregoing discussion has been limited to the more frequent considerations voiced by the courts. It becomes apparent on analysis, however, that the factors which are relied upon by the courts are by no means well-defined and distinct, but are frequently simply different ways of expressing the same basie consideration. It would seem that the courts are not weighing with great care the particular considerations as such, but are in reality taking cognizance of their cumulative effect in the light of broader policy considerations. On the one hand, the courts have expressed an awareness that the legal fee must be fixed where public standards will approve $; 37$ on the other the very nature of the legal profession demands that the competent lawyer be well compensated for his work. The importance of the last factor was artistically expressed in the case of Donaldson $v$. Allen $:^{38}$ "The ancient rule which forbids muzzling the ox which treadeth out the corn is applicable to lawyers and their fees." But as emphasized in the concluding provision of Section 12 of the Canons of Ethics: "It should never be forgotten that the profession is a branch of the administration of justice and not a mere money-getting trade." Emphatic judicial recognition of this limitation appears in the early case of Hunt $v$. Orleans Cotton Press Co. in which the court said :39

"[Lawyers should] remember ...., that they ... are in some degree compensated for their labor, and time spent in anxious search after knowledge by the respect and regard entertained for them generally, and by the opportunities so often afforded of impressing on the age in which they live, the spirit and genius which animate them. To an elevated mind this is a high reward."

\footnotetext{
${ }^{34}$ Robbins v. Jones, 211 Ky. 211, 277 S.W. 333 (1925).

35 Parker v. New England Oil Corp., 13 F.2d 158 (Mass. 1926).

${ }^{30}$ Henriques v. Vaccaro, 218 La. 1020, 51 S.2d 611 (1951).

${ }^{3}$ Bricheld $\nabla$. Dipietro, supra note 11.

s8 213 Mo. 293, 298, 111 S.W. 1128, 1129 (1908).

392 Rob. 404, 406 (La. 1842).
} 